\title{
Membrane Filtration of Milk: Separation and Fractionation of Milk Proteins
}

\author{
Kadir Cinar ${ }^{1}$
}

1* Department of Food Engineering, Trakya University, 22000 Edirne, TURKEY

\begin{abstract}
Cite this paper as:
Cinar, K. (2022). Membrane Filtration of Milk: Separation and Fractionation of Milk Proteins.Journal of Innovative Science and Engineering.6(1):61-75
\end{abstract}

*Corresponding author: Kadir Cinar E-mail: kadircinar@trakya.edu.tr

Received Date: $11 / 06 / 2021$

Accepted Date:02/12/2021

(C) Copyright 2022 by

Bursa Technical University. Available online at http://jise.btu.edu.tr/

\section{(c) (i) (8)}

The works published in Journal of Innovative Science and Engineering (JISE) are licensed under a Creative Commons Attribution-NonCommercial 4.0 International License.

\section{Abstract}

Whey is the major by-product of cheese industry which contains valuable organic materials. Further processes are needed before these organic materials can be used in food industry. Membrane filtration is a convenient alternative to traditional processes. Low energy consumption, reduced processing costs and enhanced quality of products are the main benefits of membrane filtration. Due to these advantages membrane filtration techniques have affected dairy industry in many aspects and become important part of the dairy processing. Pressure driven membrane filtration techniques namely, microfiltration (MF), ultrafiltration (UF), nanofiltration (NF) and reverse osmosis (RO) have found wide range of application areas to produce value-added dairy products. Depending on their application ranges, all the milk components can be separated and fractionated efficiently. In this paper, a comprehensive review is presented on the researches and developments related to membrane separation and fractionation of milk proteins.

Keywords: membrane filtration; milk proteins; whey separation; protein fractionation. 


\section{Introduction}

Separation technologies benefit from the physical and chemical characteristics of the mixture components. These technologies are used to separate or purify mixtures [1]. Membrane-based separation processes (Figure 1) unlike others (evaporation, ion exchange, electrodialysis etc.) do not require addition or removal of heat or chemicals that affects physical and chemical specifications of the target components. Therefore, using membrane techniques provide separations at lower temperatures which target components can be obtained at their native state $[2,3]$.

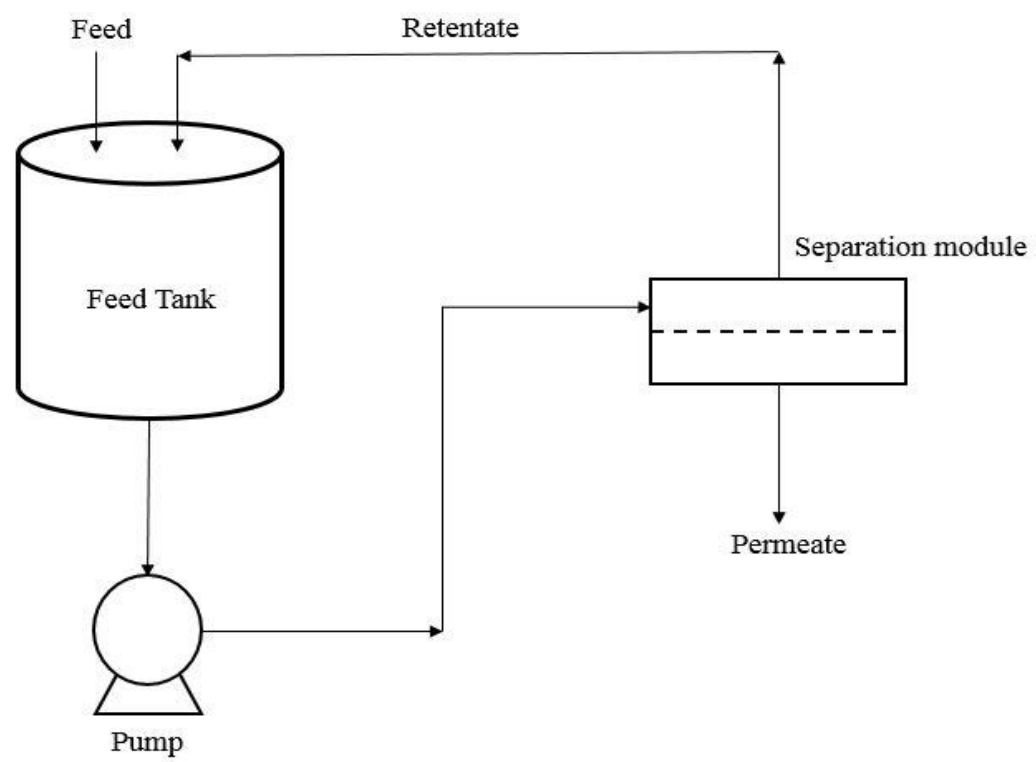

Figure 1. Schematic representation of membrane separation process.

Microfiltration (MF), ultrafiltration (UF), nanofiltration (NF) and reverse osmosis (RO) are the most common pressuredriven membrane processes used in the dairy industry. Also, based on their pore sizes and molecular weight cut-offs (MWCOs), shown at Table 1, it is possible to separate or fractionate components of the milk from casein micelles to monovalent ions $[4,5]$.

Table 1. Size distribution among filtration methods [2, 6-9].

\begin{tabular}{|c|c|c|c|}
\hline Filtration Method & $\operatorname{MWCO}(\mathbf{k D a})$ & Pore Diameter (nm) & Pressure (bar) \\
\hline Microfiltration & $>200$ & $50-10000$ & 1 \\
\hline Ultrafiltration & $1-200$ & $10-100$ & $1-15$ \\
\hline Nanofiltration & $0.3-1$ & $1-10$ & $20-30$ \\
\hline Reverse Osmosis & 0.1 & - & $10-50$ \\
\hline
\end{tabular}

Main driving force, refers to transmembrane pressure (TMP), is the pressure gradient between the side of retentate and permeate. The fraction retained by membrane is called as retentate whereas the fraction passes through membrane is 
referred as permeate [10]. Chemical composition of the membrane, temperature, pressure, feed flow and interactions of feed components with the membrane surface influence the separation performance [9]. It has been reported that UF is the most prevalent membrane filtration method in dairy industry with an installed area of about $350000 \mathrm{~m} 2$. For NF, RO and MF this area is about $100000 \mathrm{~m} 2,65000 \mathrm{~m} 2$ and $15000 \mathrm{~m} 2$, respectively [11].

In filtration process, organic polymers or inorganic materials (mostly ceramic) are used to produce membranes. Organic polymers, compared with inorganic membranes, are economically convenient and have high package density. They have a broad range of pore sizes which can perform in limited ranges of temperature, $\mathrm{pH}$, and TMP. On the other hand, inorganic materials can be used in more extreme cases and serves longer physical life [10].

Membrane processes have been taken part in dairy industry for a long time and recently they have a wide range of implementation for the concentration of whey and milk. Whey processing is the leading industrial membrane application because of the simplicity, urgency and the economics of disposal problems [12]. Besides, separation and fractionation of milk and whey proteins draw increasing interest in food industry due to their functional, biological and nutritional properties. Whey protein fractionation provides recovery of value-added protein ingredients like whey protein concentrates (WPC) and isolates (WPI). Furthermore, well-established and clean process nature of membrane separation processes not only suitable for industrial scale-up but also considerably cost effective [13]. In this study, the literature on separation and fractionation of milk and whey proteins were discussed. It was aimed to give an overview about membrane techniques which take part in full fractionation of the milk proteins.

\subsection{Properties of whey and milk proteins}

Milk proteins can be categorized into three nitrogen fragments: caseins ( $\alpha$ s1-, $\alpha$ s-, $\beta-$, and $\kappa$-casein), whey proteins ( $\alpha-$ lactalbumin ( $\alpha$-LA), $\beta$-lactoglobulin ( $\beta$-LG), bovine serum albumin (BSA), immunoglobulins (Ig)) and the nonprotein nitrogen (NPN). Caseins, whey proteins and nonprotein nitrogen fractions composed 78\%, $17 \%$ and $5 \%$ of total milk proteins, respectively. [14]. These milk proteins show different characteristics with respect to size, structure, physical and chemical properties (Table 2). Also, caseins and whey proteins possess distinct chemical and physical features. Composition of milk can be modified according to individual properties its components. Therefore, developed filtration processes can separate milk with respect to molecular weight of its components (Table 3) [5].

Therefore, different approaches including self-healing processes were studied to improve the material properties and process. 
Table 2. Approximate concentration and size distrubution of the milk components [15-18].

\begin{tabular}{|c|c|c|c|}
\hline Component & $\begin{array}{l}\text { Concentration } \\
\text { in milk } \\
\left(\mathrm{g} \mathrm{L}^{-1}\right)\end{array}$ & $\begin{array}{l}\text { Concentration in } \\
\text { Gouda cheese whey } \\
\left(\mathrm{g} \mathrm{L}^{-1}\right)\end{array}$ & Size range \\
\hline Water & 871 & 935 & - \\
\hline Fat globules & 40 & 0.5 & $\begin{array}{c}0.1-15 \mu \mathrm{m} \\
\text { average } 3.4 \mu \mathrm{m}\end{array}$ \\
\hline Casein & 26 & - & $\begin{array}{c}20-300 \mathrm{~nm}, \\
\text { average } 110 \mathrm{~nm}\end{array}$ \\
\hline$\alpha_{\mathrm{s} 1}$-Casein & 10 & - & $23 \mathrm{kDa}$ \\
\hline$\alpha_{\mathrm{s} 2}-$ Casein & 2.6 & - & $25 \mathrm{kDa}$ \\
\hline$\beta$-Casein & 9.3 & - & $24 \mathrm{kDa}$ \\
\hline$\kappa$-Casein & 3.3 & - & $19 \mathrm{kDa}$ \\
\hline$\alpha$-Lactalbumin & 1.2 & 3 & $14 \mathrm{kDa}$ \\
\hline$\beta$-Lactoglobulin & 3.2 & 1.2 & $18 \mathrm{kDa}$ \\
\hline Immunoglobulins & 0.8 & 0.7 & $150-900 \mathrm{kDa}$ \\
\hline Serum albumin & 0.4 & 0.4 & $66 \mathrm{kDa}$ \\
\hline Lactoferrin & 0.1 & 0.045 & $86 \mathrm{kDa}$ \\
\hline Transferrin & 0.1 & - & $76 \mathrm{kDa}$ \\
\hline Proteose-pepton & 0.8 & 0.6 & $4-40 \mathrm{kDa}$ \\
\hline Lactose & 46 & 47 & $350 \mathrm{kDa}$ \\
\hline
\end{tabular}


Table 3. Application of membrane separation in dairy industry.

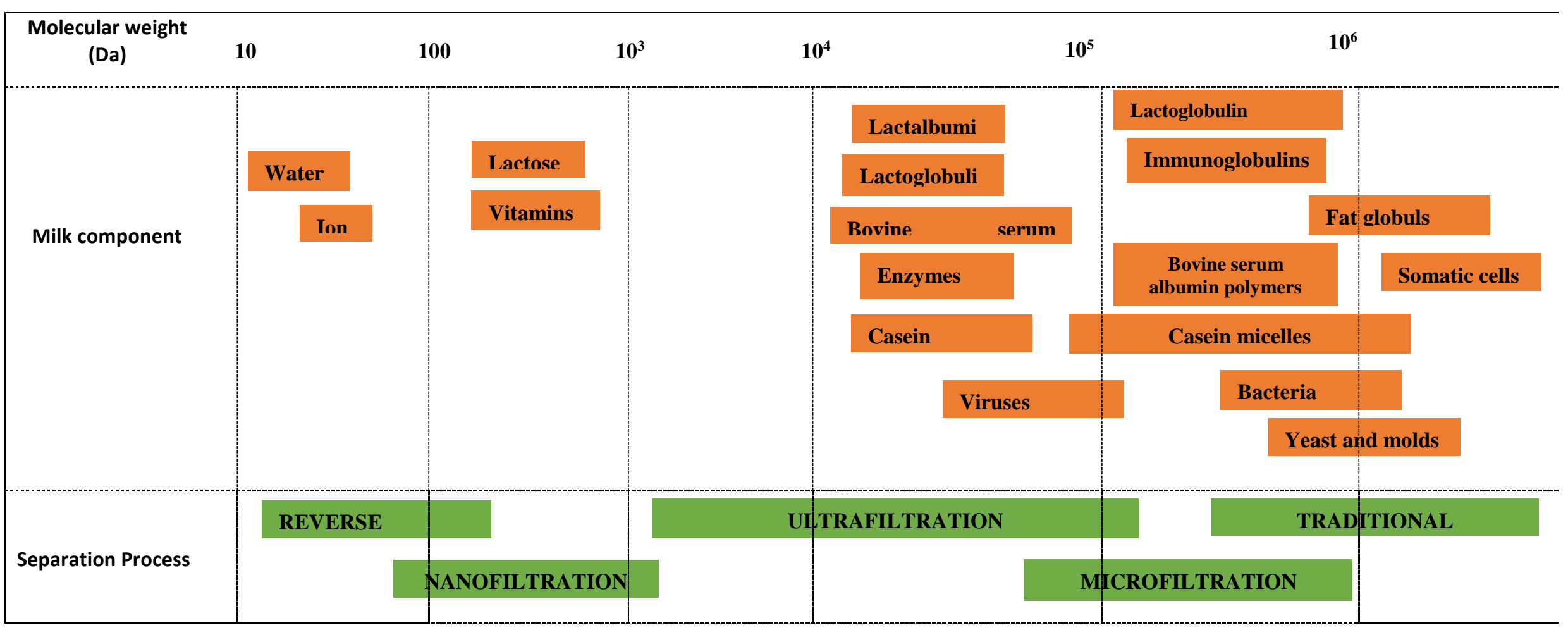




\section{Membrane Filtration Methods}

\subsection{Microfiltration}

MF can selectively provide separation of particles that have MWCO of larger than $200 \mathrm{kDa}$ (Table 1). It is a pressure driven system usually working at transmembrane pressure of the order of 1 bar. Pore diameters of MF membranes are between 0.05 to $10 \mu \mathrm{m}[7]$.

Membranes are manufactured mainly from ceramics and polymers for dairy industry. Most of the MF membranes are formed from polymeric materials, but inorganic materials are also widely used: aluminum (Al) oxide, zirconium ( $\mathrm{Zr}$ ) oxide, titanium (Ti) oxide, carbon, silica carbide, and various metals such as steel, tin, nickel, etc. [19]. Manufacturing of polymeric membranes cost less but they are sensitive to chemicals and high temperatures. Therefore, polymeric membranes have limited lifetime [20]. On the other hand, ceramic membranes that have wide range $\mathrm{pH}$ stability (0 to 14) and temperature resistance over $100^{\circ} \mathrm{C}$ provides remarkable advantages over the polymeric membranes with regard to chemical, thermal, and mechanical stability [2].

In dairy industry, MF has found many application areas due to various range of pore size. MF is primarily applied for the removal of bacteria and spores from skim milk to reduce the bacterial load [21, 22]. Bacteria in milk have size ranges between 0.4-2.0 $\mu \mathrm{m}[15]$ and thus pore diameters of 1 to $2 \mu \mathrm{m}$ MF membranes are used for removal of microorganisms. MF membranes having different pore sizes are also used for casein enrichment. Fractionation of milk proteins can be done with the help of advanced MF membranes which have pore sizes between 0.05-1.0 $\mu \mathrm{m}$ [23]. MF of milk provides retention almost all of the casein in the retentate and passage of a great majority of whey protein into the permeate fraction [24, 31]. MF produces a permeate which contains mainly $\beta$-LG, $\alpha$-LA, lactose, minerals, and NPN [25]. Micellar casein concentrate is obtained by MF of skim milk to use in manufacturing of cheese or production of milk proteins concentrates [24].

Ceramic membranes having pore size between 0.05 and $0.20 \mu \mathrm{m}$ can be used to concentrate the casein micelles of skim milk. Typically, MF is performed at a temperature of $5-55^{\circ} \mathrm{C}$ and $\mathrm{pH}$ of 6.0 to 6.8 at a concentration factor of 3-fold to 6-fold for a period of time ranging from 1-18 hours [24]. In order to decrease fouling rate, high cross-flow velocities are needed, often in combination with the uniform TMP [22] which copes with the most of the heterogeneous fouling of the MF membranes [15, 22]. Micellar casein concentration can be achieved by applying MF to full fat milk or skimmed milk. Then, by using diafiltration (DF) procedures, $90 \%$ of casein purification can be done on a total basis [26]. DF is a kind of membrane process provides reduction of soluble permeate components by dilution and filtration of retentate several times. Thus, concentration of retained component is increased in the retentate [27].

In traditional manufacturing of cheese, most of the whey proteins are not retained in the cheese and passes through to the whey. However, they undergo denaturation during the cheese making process [28]. However, when the MF retentate is used for the production of cheese, whey proteins are separated in native form before the cheese production [24]. MF permeate is named as "ideal whey" because of its composition and characteristics. It has sterile composition which contains commercially extractable amounts of non-denatured and native state whey proteins. Unlike traditional whey it does not involve measurable amount of fat or casein and also glycomacropeptides, rennet or starter culture [24, 29]. For this reason, MF permeate can be directly used as a feed to use for separation and purification of whey proteins without 
any pretreatment [30]. Cross flow microfiltration is a useful method for production of pure $\alpha$-LA and $\beta$-LG rich fractions from milk [31].

Serum proteins $(0.003-0.010 \mu \mathrm{m})$ are soluble in milk whereas casein exists as colloidal micelles $(0.02-0.40 \mu \mathrm{m})$ [32]. Therefore, MF separation of skim milk with pore sizes of 0.05-0.1 $\mu \mathrm{m}$ provides retentate with rich of casein and permeate with rich of whey proteins. Casein concentrated with MF is a colloidal suspension of micellar casein, a little amount of whey proteins, lactose and minerals. Depending on the targeted concentration factor or weight reduction factor, 60 to 95\% (w/w) of whey proteins of skim milk can be passed to the permeate [33]. Native micellar casein and its co-product, the WPI, are obtained after the subsequent step of UF of MF milk. They are further processed to fractionate and isolate individual caseins and whey proteins [34]. Furthermore, it is necessary to use combinations of membranes in order to get highly concentrated or purified protein fractions. Commercial MF membranes are manufactured with specific pore sizes. For this reason, using combination of membranes can provide to get different fractions of a single feed.

The major concern with MF is fouling that causes decreasing rates of permeate flux and membrane selectivity [35]. Using MF to concentrate micellar casein cause membrane fouling which decreases permeation of whey proteins [15]. In order to decrease fouling, high cross-flow velocity and constant flux methods are commonly used [36]. However, these two methods together with cleaning procedures cause high cost and lower productivity. Although there are various fouling control methods in literature, it has been reported that back pulsing is a good controller of fouling in MF of skim milk [36]. Addition to this, back pulsing provides energy saving by decreasing the cross-flow velocity requirements during MF. Arkell, Vrgoc [37] have used $1.4 \mu \mathrm{m}$ ceramic membrane in order to MF of skim milk and according to their findings, back pulsing method can only be efficient only at lower flux rates.

Temperature is important for casein concentration in order to maintain milk viscosity at low constant level without inducing any reactions [38]. In literature, some of the MF experiments done for the casein concentration are shown at the Table 4. Concentration factor is defined as the weight of skim milk (feed) divided by the weight of permeate. In order to get higher casein concentrate, some experiments shown below also involves DF step.

Table 4. Concentration of casein with MF from skim milk [29, 31, 39-41].

\begin{tabular}{|c|c|c|c|c|}
\hline \multirow[b]{2}{*}{ Membrane } & \multirow{2}{*}{$\begin{array}{c}\text { Concentration } \\
\text { Factor }\end{array}$} & \multicolumn{3}{|c|}{ Retentate Composition } \\
\hline & & Total Solid (\%) & True Protein (\%) & Casein (\%) \\
\hline $0.05 \mu \mathrm{m}$ ceramic & 2.50 & 12.54 & 7.27 & 5.29 \\
\hline $0.10 \mu \mathrm{m}$ ceramic & 2.30 & 11.14 & 5.79 & 5.04 \\
\hline $0.10 \mu \mathrm{m}$ ceramic & 1.26 & 9.13 & 3.65 & 2.88 \\
\hline $0.10 \mu \mathrm{m}$ ceramic & 1.51 & 9.72 & 4.23 & 3.45 \\
\hline $0.10 \mu \mathrm{m}$ ceramic & 1.82 & 10.37 & 4.15 & 4.15 \\
\hline $0.14 \mu \mathrm{m}$ ceramic & 3.02 & 10.56 & 8.52 & 7.45 \\
\hline $0.20 \mu \mathrm{m}$ ceramic & 2.50 & 10.77 & - & 4.93 \\
\hline $0.30 \mu \mathrm{m}$ PVDF & 1.50 & 10.03 & 4.48 & 3.68 \\
\hline $0.30 \mu \mathrm{m}$ PVDF & 3.00 & 14.06 & 7.71 & 6.67 \\
\hline
\end{tabular}

Samuelsson, Dejmek [42] have used $0.14 \mu \mathrm{m}$ tubular ceramic membrane to filter skim milk in order to get optimum parameters for fractionation of casein and whey products. They reported whey protein content decreased in the permeate 
with low circulation velocities at low temperatures. According to their findings, the retention of whey proteins was $12 \%$ at $8 \mathrm{~m} \mathrm{~s}-1$ circulation velocity and at $55^{\circ} \mathrm{C}$ while it was $39 \%$ at $6 \mathrm{~m} \mathrm{~s}-1$ circulation velocity and at $15^{\circ} \mathrm{C}$. In another study, Lawrence, Kentish [21] used 0.3 and $0.5 \mu$ m polyvinylidene flouride (PVDF) MF membranes in order to filter the milk. They found that increase in TMP causes higher rejection of total casein and lower rejection of $\beta$-LG. In their experiments, permeate flux with $0.3 \mu \mathrm{m}$ membranes show variation between 6 to $18 \mathrm{~L} \mathrm{~m} 2 \mathrm{~h}-1$ with $98 \%$ casein and $69 \% \beta$-LG retention at $10^{\circ} \mathrm{C}$ with 1.5 bar TMP and $0.4 \mathrm{~m} \mathrm{~s}-1$ tangential flow rate. Also, it has been reported that at a mean TMP of $137.9 \mathrm{kPa}$ with a cross flow velocity of $5.4 \mathrm{~m} \mathrm{~s}-1$ at $50^{\circ} \mathrm{C}, 0.05 \mu \mathrm{m}$ ceramic membrane can retain all the caseins and allows only $\beta$-LG and $\alpha$-LA and smaller molecular weight component to pass through [31]. Since casein micelle sizes are between 20-200 nm and serum proteins size are between 3-6 nm, this result is possible. According to their results, $0.05 \mu \mathrm{m}$ MF membrane is good separator of casein from milk. By using this membrane, all of the casein can be retained in the retentate and most of the $\alpha$-LA and $\beta$-LG can be collected in permeate [31]. In similar study, Kuperus, Janakievski [43] reported that at higher temperatures, milk viscosity decreases and thus flux rates and whey protein permeation increases. However, longer membrane filtration processes at high temperatures such as $50^{\circ} \mathrm{C}, \alpha-\mathrm{LA}$ and $\beta$-LG permeation capacities are declined due to denaturation of the proteins.

\subsection{Ultrafiltration}

UF can selectively provide separation of macromolecules having molecular weights of 1 to $200 \mathrm{kDa}$ from solvent and dissolved solutes which is equal to a nominal pore diameter of 10 to $100 \mathrm{~nm}$ [8]. Pressure ranges in UF varies 1 to 15 bar which is very lower than RO and NF [6]. Due to its advantages like industrial familiarity and ease of scale-up UF can be used in different areas in the dairy industry.

UF membranes can be produced either of polymers or of inorganic materials mainly $\mathrm{Al}$ and Ti oxides [19]. Traditionally UF used in dairy applications utilizes polysulfone membranes due to their low cost and superior mechanical properties. Although it is considered that hydrophobic polysulfone membranes causes lower fluxes with critical fouling degrees than ceramic and hydrophilic polysulfone membranes, Doyen, Adriansens [44] showed that almost the same flux and whey permeability coefficients are obtained with ceramic and polysulfone membranes during whey processing.

Fractionation of whey proteins with UF is a complex process due to the fact that parameters affects the protein transmission or protein rejection of the membrane. Some of these parameters are flux, TMP, porosity and morphology, surface charge and hydrophilicity or hydrophobicity of the membrane etc. [45]. The molecular weights of the main serum proteins are very close to each other which are $14 \mathrm{kDa}$ and $18 \mathrm{kDa}$ and thus purification of these proteins with UF becomes difficult. Besides, since the isolelectric points of these proteins are also very close to each other (4.5-4.8 for $\alpha$-LA and 5.2 for $\beta$-LG), efficient separation could not be achieved by using of electrostatic interactions between the membrane and the proteins [46]. Therefore, protein fractionation by UF has some technical challenges in order to separate similar size components. It is possible to increase selectivity of UF membranes by adjusting the solution $\mathrm{pH}$, salt concentration or system hydrodynamics. However, it should not be forgotten that while trying to obtain high selectivity, membrane fouling has to be keep in minimum amount in order to have successful fractionation of serum proteins [45]. Fouling affects membrane performance adversely that causes to decrease in membrane life and also increase in cleaning costs.

The permeate of MF skim milk can be further performed by UF to obtain high class WPC. For example, UF of this permeate provides a WPC which has $77 \%$ protein (dry base) and by means of DF this value can be increased to over 
$90 \%$ to obtain WPI $[34,47]$. The WPC and WPI can be further processed to obtain lactoferrin, $\beta$-LG and $\alpha$-LA by using ion-exchange chromatography. Also, it is possible to separate these serum proteins by applying UF to the MF permeate at $50^{\circ} \mathrm{C}$. In this way, $\beta$-LG will be retained in the retentate but $\alpha$-LA will pass in the permeate $[24,48,49]$.

Atra, Vatai [50] used polyvinyl-difluoride and polyethersulfone UF membranes in order to concentrate serum proteins and they reported that at $50^{\circ} \mathrm{C}, 92-98 \%$ protein rejection was reached while the flux was $30 \mathrm{~L} \mathrm{~m}-2 \mathrm{~h}$ at approximately at 3 bar. On the other hand, Baldasso, Barros [51] used $10 \mathrm{kDa}$ polyethersulfone membrane in order to perform UF of whey followed by $\mathrm{DF}$ at $50{ }^{\circ} \mathrm{C}$ and TMP of 2 bar with a feed flow rate of $840 \mathrm{~L} \mathrm{~h}-1$. They achieved $71 \%$ of total protein purification by weight (dry basis). Moreover, Holland, Kackmar [52] used $100 \mathrm{kDa}$ UF membrane to fractionate $\alpha$-LA from skim milk. According to their results, the recovery of $\alpha$-LA in the permeate was only $10 \%$ and the enrichment of retentate with $\beta$-LG was not achieved. However, Arunkumar and Etzel [53] used $300 \mathrm{kDa}$ charged regenerated cellulose UF membrane to fractionate $\alpha$-LA and $\beta$-LG from milk-serum permeate and they achieved $180 \%$ greater selectivity than uncharged membranes. Moreover, they managed to purify $\alpha$-LA to $87 \%$ and $\beta$-LG to $83 \%$. These results shows that separation of milk proteins was influenced from surface morphology and internal structure of the membranes. In charged UF membranes phenomena such as electrostatic interactions and Donnan effects can occur and thus these can affect the separation mechanisms [5]. Also, it is clear that these studies show that UF membranes associated with DF can be used not only to concentrate serum proteins but also to fractionate milk and whey proteins.

\subsection{Intrinsic Self-Healing}

Separation of solvent, monovalent salts, small organics from diavelent ions and larger species can be performed by NF process. In dairy industry, NF is widely used to concentrate and partially demineralize whey solution since demineralization increases the nutritional value of the products. NF is an alternative to other methods (evaporation, electrodialysis) for partial demineralization of whey for energy-saving, high-quality and protein-rich products meant for nutritional use as it reduces the processing costs as well. NF membranes have MWCO from 0.3-1 kDa with pore sizes between 1 and $10 \mathrm{~nm}$ and the operating pressure is in the region of 20-30 bar [9]. Actually, NF is a process between UF and RO with respect to MWCO and permeability [7]. The size and length of pores, material and charge of membrane, viscosity, $\mathrm{pH}$, ionic strength, ion valency and salt composition are the major characteristics of membrane and feed that affect separation processes importantly [54]. Also, the selectivity of NF membrane is important feature for separating lactose from lower molecular weight/ionic species since major amount of monovalent ions, organic acids, and a little amount of lactose can pass through the membrane [55]. Moreover, NF membranes have negative charge at their surfaces [9], thus charge interaction plays a dominant role, which means that the separation mechanisms of NF membranes consist of steric and electrical effects [56].

During the NF of milk/whey, small molecules are removed along with water whereas larger molecules (lactose, protein and fat) are retained. NF provides concurrently separation and concentration of minerals [50]. Lactose or demineralized whey production was obtained by partial removal of acid and mineral from acid and sweet whey, respectively [9]. Nowadays, technologically developed NF membranes can be used concentrate liquid WPC and WPI before entering spray drying process, thus crucial amount of energy saving in drying processes are performed [7].

UF and MF permeates are concentrated or demineralized by using NF [2]. It is desirable for manufacturing lactose or lactose derivatives from the permeates of UF operations. According to a study $90 \%$ of lactose yield achieved by using polyamide membrane which has MWCO of $400 \mathrm{Da}$ at proper operating conditions [50]. In another study, Lipnizki [4] 
stated that by using NF mineral content of whey can be decreased about 35\% and this value of mineral reduction is possible to get increased up to $45 \%$ by using DF step. Furthermore, approximately $35 \%$ demineralization was achieved while concentrating total solid to $20-22 \%$ by using thin film composite membranes [55]. However, Pan, Song [57] indicated that approximately $72 \%$ of ash removal is acquired through the DF step at their study. Also, they pointed out that at different $\mathrm{pH}$ of feeds the degree of demineralization changes. They obtained best demineralization $\mathrm{pH}$ as 4.60 which is the isoelectric point of whey proteins.

NF also can be used for fractionating of whey peptides. Depends on the MWCO of the UF membranes, UF permeate may contain lactose, salts, peptides, amino acids and non-protein nitrogen. NF is a proper membrane process for separation or fractionation of these peptides due to the suitable MWCO of the membranes and the electrochemical effects [58]. According to a study which reported that polypeptide separation can be achieved from lactose, UF permeate was passed through to $1 \mathrm{kDa}$ polyether sulfone NF membrane at $\mathrm{pH}$ values 9.5 and 3.0. Results of this study indicates that selectivity of the NF membranes toward peptides with respect to lactose was 0.82 and 6.81 at $\mathrm{pH} 9.5$ and 3.0, respectively. Therefore, researchers concluded that the purification of peptides was mainly affected by the fouling layer structure at acidic $\mathrm{pH}$ and by low flux value [59]. Moreover, Nguyen, Reynolds [60] pointed out the potential of applying $\mathrm{NF}$ on other by-product streams to concentrate protein and lactose in order to reduce treatment cost and recover more daily solids.

\subsection{Reverse Osmosis}

RO provides selectively separation of molecules having molecular weight of approximately $0.1 \mathrm{kDa}$ with pressure between 10-50 bar which is 5-10 times higher than the pressure occurred in UF [9].

The separation by RO is achieved with pressure driven diffusion process, not by the size of the solute unlike UF. Also, RO membranes are consisting of an ultra-thin nonporous skin layer and singular configured films made from synthetic organic polymers. RO is commonly used for concentration of milk or whey by removing of water and ionized minerals. The dairy residual can be concentrated by RO and NF membranes at low temperatures. The osmotic pressure of skim milk or whey is about $0.7 \mathrm{MPa}$ during RO. However, it is observed that in order to concentrate milk or whey to $25 \%$ $(\mathrm{w} / \mathrm{w})$ dry matter by RO, increase in osmotic pressure is required up to 2.7-3.5 $\mathrm{MPa}$ [47]. Increasing osmotic pressure has a limiting effect on permeate flux and retentate concentration. Transport of components occurs by diffusion through the thin layer of the semipermeable membrane. The rate of transportation is affected by the solubility and diffusivity of the component in the membrane [47].

The main application area of RO is the pre-concentration of whey due to low energy consumption $(9 \mathrm{kWh})$ in comparison with vacuum evaporation ( 9 to $150 \mathrm{kWh}$ ) [34]. Limit of concentration of whey is up to $18-27 \%$ dry matter since after this point filtration performance affects negatively by the reason of the increase in osmotic pressure and viscosity of retentate along with the crystallization of lactose and precipitation of calcium phosphate. The high salt content also causes some problems during process such as slow lactose crystallization rate and nutritional imbalance in human food. Therefore, demineralizing is an important step before evaporation and drying to achieve higher productivity [34]. 


\section{Conclusion}

In this review, we deal with the current applications of membrane technology used for separating or fractionating milk and whey proteins. Membrane separations can be recognized as a valid choice to conventional techniques or as a novel food processing technique since it is considered as green technology. There is a widespread implementations of membrane techniques in several fields including dairy industry as well. The fractionation techniques like membrane filtration is the best possible way to use milk components for human nutrition since it has many advantages such as, reduced energy consumption, less processing steps, more efficient separation, enhanced final product quality and being environmentally friendly. Moreover, it is important to understand the effects of membrane processing conditions on the separation and fractionation of casein and whey proteins from milk for developing innovative process to obtain highly functional whey proteins. Whey and milk components have a sustainable market future since they have a wide range of application area in food industry as additives in bakery, dairy products, meats, and beverages. However, their usage area is limited because the functionality of these products are not consistent in food industry. For this reason, there has been significant commercial interest in the production of milk and individual whey proteins with recognizable functional and nutritional properties. Recent improvements in membrane processing provides new exciting and economically convenient opportunities to obtain high-quality products with low energy consumption and low cost, meant for both functional and nutritional use. Therefore, membrane filtration technology should concentrate more on these new opportunities in order to obtain milk proteins with desired nutritional and functional level.

\section{Acknowledgements}

This research did not receive any specific grant from funding agencies in the public, commercial, or not-for-profit sectors.

\section{References}

[1] Marella, C., Muthukumarappan K., and Metzger, L. (2013). Application of membrane separation technology for developing novel dairy food ingredients. Journal of Food Processing \& Technology, 4(9).

[2] Marcelo, P.A. and Rizvi S.S. (2008). Applications of membrane technology in the dairy industry, in Handbook of Membrane Separations: Chemical, Pharmaceutical, Food, and Biotechnological Applications, CRC Press. pp. 635-669.

[3] Strathmann, H. (2000). Membrane separation processes, 1. Principles. Ullmann's Encyclopedia of Industrial Chemistry.

[4] Lipnizki, F. (2010). Cross-flow membrane applications in the food industry. Membranes for food applications. Edited by Peinemann K.V., Pereira S., Giorno L., Estados Unidos de América: Willey-VCH. pp. 1-23.

[5] Pouliot, Y. (2008). Membrane processes in dairy technology-From a simple idea to worldwide panacea. International Dairy Journal, 18(7): 735-740.

[6] Goldsmith, R.L., deFilippi, R.P., Hossain, S., \& Timmins, R.S. (1971). Industrial ultrafiltration, in membrane processes in industry and biomedicine, M. Bier. Plenum Press, New York. pp. 267-300. 
[7] Muthukumarappan, K., and Marella, C. (2010). Membrane processing. Edited by M. M. Farid , Mathematical modeling of food processing CRC Press. pp. 735-758.

[8] Mistry, V.V., and Maubois, J.L. (1993). Application of membrane separation technology to cheese production. Edited by P. F. Fox, Cheese: Chemistry, Physics and Microbiology Chapman \& Hall, London, England. pp. 493-521.

[9] Salehi, F. (2014). Current and future applications for nanofiltration technology in food processing. Journal of Food and Bioproducts Processing, 92(2): 161-177.

[10] Le, T.T., Cabaltica, A.D., and Bue, V.M. (2014). Membrane separation in dairy processing. Journal of Food Research and Technology, 2(1): 1-14.

[11] Garcia, L.F., Blanco, S.A., and Riera, F.A. (2012). Microfiltration applied to dairy streams: Removal of bacteria. Journal of Food Agriculture, 93(2): 1981-1900.

[12] Akpinar-Bayizit, A., Ozcan T., and Yilmaz-Ersan L. (2009). Membrane processes in production of functional whey components. Mljekarstvo: časopis za unaprjeđenje proizvodnje i prerade mlijeka, 59(4): 282-288.

[13] Marella, C. (2009). Whey protein fractionation using membrane separation technology. PhD thesis, South Dakota State University. Brookings, USA. 186 p.

[14] Dupont, D., Croguennec T., and Pochet S. (2018). Milk Proteins-Analytical Methods. Reference Module in Food Science. p. np.

[15] Brans, G., Schroën, C.G.P.H., van der Sman, R.G.M., and Boom, R.M. (2004). Membrane fractionation of milk: state of the art and challenges. Journal of Membrane Science, 243(1): 263-272.

[16] De Wit, J.N. (2001). Lecturer's Handbook on whey and whey products. European Whey Products Association, Brussels, Belgium.

[17] Walstra, P., Geurts, T.J., Noomen, A., Jellema, A., van Boekel, M. A. J. S. (1999). Dairy TechnologyPrinciples of milk properties and processes. Marcel Dekker, New York, NY.

[18] Ng-Kwai-Hang, K. F. (2011). Milk proteins heterogeneity, fractionation, and isolation. Edited by J. W. Fuquay, P. F. Fox, P. L.H. McSweeney, Encyclopedia of dairy sciences, Second Edition, McGill University, Montreal, QC, Canada: Elsevier Ltd. pp. 751-764.

[19] Luque, S., Gómez, D., and Álvarez, J. R. (2008). Industrial applications of porous ceramic membranes (pressure driven processes). Journal of Membrane Science and Technology 13: 177-216.

[20] Schier, G., and Paar, S. (2007). Standardization of casein using different membranes. Evaluation of the crossflow microfiltration of milk. Lebensmittelindustrie und Milchwirtschaft, 128: 22-25.

[21] Lawrence, N.D., Kentish, S.E., O`Connor, A.J., Barber, A.R. and Stevens, G.W. (2008). Microfiltration of skim milk using polymeric membranes for casein concentrate manufacture. Separation and Purification Technology, 60: 237-244.

[22] Saboya, L.V., and Maubois, J. L. (2000). Current developments of microfiltration technology in the dairy industry. Journal of Le Lait, 80(6): 541-554.

[23] Hayaloğlu, A., and Özer, B. (2011). Peynir biliminin temelleri. Sidas Medya Ltd.

[24] Ur-Rehman, S., Dunker, J. M. (2010). Methods for Casein Production. Patent, 12/741,034 (US 2010/0303958 A1) Winstead PC, Dallas, United States. 
[25] Zulewska, J., Newbold, M., \& Barbano, D.M. (2009). Efficiency of serum protein removal from skim milk with ceramic and polymeric membranes at $50^{\circ} \mathrm{C}$. Journal of Dairy Science, 92(4): 1361-1377.

[26] Maubois, J.L., and Ollivier, G. (1992). Milk Protein Fractionation. Edited by R. de Boer, P. Jelen, Z. Puhan, New Applications of Membrane Processes IDF Special Issue, 9201. Brussels, Belgium. pp. 15-22.

[27] Kumar, P., Sharma, N., Ranjan, R., Kumar, S., Bhat, Z.F., and Jeong, D.K. (2013). Perspective of membrane technology in dairy industry: A Review. Asian-Australasian Journal of Animal Sciences, 26(9): 1347-1358.

[28] Nelson, B.K., and Barbano, D.M. (2005.) A microfiltration process to maximize removal of serum proteins from skim milk before cheese making. Journal of Dairy Science, 88(5): 1891-1900.

[29] Dong, J.Y., Chen, L.Y., Maubois, J.L., and Ma, Y. (2009). Influence of medium concentration factor microfiltration treatment on the characteristics of low-moisture Mozarella cheese. Journal of Dairy Science and Technology, 89(2): 139-154.

[30] Maubois, J. L., Pierre, A., Fauquant, J., and Piot, M. (1987). Industrial fractionation of the main whey proteins. Bulletin of the International Dairy Federation, 212: 154-159.

[31] Punidadas, P., and Rizvi, S. S. H. (1998). Separation of milk proteins into fractions rich in casein or whey proteins by cross flow filtration. Food Research International, 31(4): 265-272.

[32] Walstra, P., Wouters, J.T.M., and Geurts, T.J. (2006). Dairy Science and Technology: Second Edition. Boca Raton, Florida: CRC Press, Taylor \& Francis Group.

[33] Beckman, S.L., Zulewska, J., Newbold, M., and Barbano, D.M. (2010). Production efficiency of micellar casein concentrate using polymeric spiral-wound microfiltration membranes. Journal of Dairy Science, 93(10): 4506-4517.

[34] Daufin, G., Escudier, J.P., Carrere, H., Berot, S., Fillaudeau, L., and Decloux, M. (2001). Recent and emerging applications of membrane processes in the food and dairy industry. Food and Bioproducts Processing, 79(2): 89-102.

[35] Marshall, A.D., Munro, P.A., and Tragardh, G. (1993). The effect of protein fouling in microfiltration and ultrafiltration on permeate flux, protein retention and selectivity: a literature review. Journal of Desalination, 91(1): 65-108.

[36] Arkell, A., Vrgoc, F., and Jönsson, A.S. (2014). Back-pulsing as an energy-saving method in the microfiltration of milk. International Dairy Journal, 35(1): 1-5.

[37] Arkell, A., Vrgoc, F., Wallberg, O., and Jönsson, A.S. (2015). Increasing flux by back-pulsing in the microfiltration of milk. International Dairy Journal, 41: 23-25.

[38] Rizvi, S. S. H., and Brandsma, R. L. (2003). Microfiltration of skim milk for cheese making and whey proteins. Patent, 10/255,085 (US 6,623,781 B2) Cornell Research Foundation, Inc., Ithaca, NY, United States.

[39] Adams, M.C., \& Barbano, D.M. (2013). Serum protein removal from skim milk with a 3-stage, 3×ceramic Isoflux membrane process at $50^{\circ}$ C. Journal Dairy Science, 96(4): 2020-2034.

[40] Beckman, S.L., and Barbano, D.M. (2013). Effect of microfiltration concentration factor on serum protein removal from skim milk using spiral-wound polymeric membranes. Journal of Dairy Science, 96(10): 61996212.

[41] Neocleous, M., Barbano, D.M., and Rudan, M.A. (2002). Impact of Low Concentration Factor Microfiltration on the Composition and Aging of Cheddar Cheese. Journal of Dairy Science, 85(10): 2425-2437. 
[42] Samuelsson, G., Dejmek, P., Trägårdh, G., and Paulsson, M. (1997). Minimizing whey protein retention in cross-flow microfiltration of skim milk. International Dairy Journal, 7(4): 237-242.

[43] Kuperus, J. H., Janakievski, F., Glagovskaiaand, O., \& De Silva, K. (2013). Effect of pH, temperature and milk dilution on skim milk microfiltration. International Membrane Science \& Technology Conference. Melbourne, Australia.

[44] Doyen, W., Andriansens, W., Molenberghs, B., and Leysen, R. (1996). A comparison between polysulfone, zirconia and organo-mineral membranes for use in ultrafiltration. Journal of Membrane Science, 113(2): 247258.

[45] Cui, Z. (2005). Protein separation using ultrafiltration-An example of multi-scale complex systems. Journal of China Particuology, 3(6): 343-348.

[46] Lucena, M.E., Alvarez, S., Menendez, C., Riere, F.A., and Alvarez, R. (2006). Beta-lactoglobulin removal from whey protein concentrates production of milk derivatives as a base for infant formulas. Separation and Purification Technology, 52(2): 310-316.

[47] Kelly, P.M. (2011). Milk Protein Products-Membrane-Based Fractionation. Edited by J.W. Fuquay, P.F. Fox, P.L.H. McSweeney, Encyclopedia of dairy sciences, Second Edition, San Diego, Academic Press. pp. 864872.

[48] Metsämuuronen, S., Mänttäri, M., and Nyström, M. (2011). Comparison of analysis methods for protein concentration and its use in UF fractionation of whey. Journal of Desalination, 283: 156-164.

[49] Uchida, Y., Masaharu, S., Tamami, M., \& Masanobu, K. (1996). Process for preparing a fraction having a high content of $\alpha$-lactalbumin from whey and nutritional compositions containing such fractions. Patent 284,919 (US 5,503,864). Snow Brand Milk Products, Inc., Hokkaido, Japan.

[50] Atra, R., Vatai, G., Bekassy-Molnar, E., \& Balint, A. (2005). Investigation of ultra- and nanofiltration for utilization of whey protein and lactose. Journal of Food Engineering, 67(3): 325-332.

[51] Baldasso, C., Barros, T.C., and Tessaro, I.C. (2011). Concentration and purification of whey proteins by ultrafiltration. Desalination, 278(1-3): 381-386.

[52] Holland, B., Kackmar, J., and Corredig, M. (2012). Isolation of a whey fraction rich in $\alpha$-lactalbumin from skim milk using tangential flow filtration. Journal of Dairy Science, 95(10): 5604-5607.

[53] Arankumar, A., and Etzel, M.R. (2014). Fractionation of $\alpha$-lactalbumin and $\beta$-lactoglobulin from bovine milk serum using staged, positively charged, tangential flow ultrafiltration membranes. Journal of Food Membranes, 454: 488-495.

[54] Horst, H.C., Timmer, J.M.K., Robbertsen, T., and Leenders, J. (1995). Use of nanofiltration for concentration and demineralization in the dairy indusrty: Model for mass transport. Journal of Membrane Science, 104(3): 205-218.

[55] Kelly, J., and Kelly, P. (1995). Desalination of acid casein whey by nanofiltration. International Dairy Journal, 5(3): 291-303.

[56] Rasanen, E., Nyström, M., Sahlstein, J., and Tossavainen, O. (2002). Comparison of commercial membranes in nanofiltration of sweet whey. Journal of Lait, 82(3): 343-356.

[57] Pan, K., Sing, Q., Wang, L., and Cao, B. (2011). A study of demineralization of whey by nanofiltration membrane. Desalination, 267(2-3): 217-221. 
[58] Pouliot, Y., Gauthier, S.F., and Heureux, J.L. (2000). Effect of peptide distribution on the fractionation of whey protein hydrolysates by nanofiltration membranes. Lait, 80(1): 113-122.

[59] Butylina, S., Luque, S., and Nyström, M. (2006). Fractionation of whey-derived peptides using a combination of ultrafiltration and nanofiltration. Journal of Membrane Science, 280(1-2): 418-426.

[60] Nguyen, M., Reynolds, N., and Vigneswaren, S. (2003). By-product recovery from cottage cheese production by nanofiltration. Journal of Cleaner Production, 11(7): 803-807. 